\title{
PERAN GREEN TRUST MEMEDIASI PENGARUH GREEN PERCEIVED VALUE DAN KEPUASAN KONSUMEN TERHADAP GREEN REPURCHASE INTENTION
}

\author{
Ni Nyoman Nuristiana Pratiwi ${ }^{1}$ \\ Ni Nyoman Kerti Yasa ${ }^{2}$ \\ ${ }^{1,2}$ Fakultas Ekonomi dan Bisnis Universitas Udayana (Unud), Bali, Indonesia \\ email: nuristianapratiwi@gmail.com
}

\begin{abstract}
ABSTRAK
Green repurchase intention merupakan kecenderungan konsumen untuk melakukan pembelian kembali terhadap produk ramah lingkungan yang sama pada masa mendatang. Tujuan penelitian ini adalah untuk mengetahui pengaruh green perceived value, kepuasan konsumen, serta green trust terhadap green repurchase intention. Penelitian ini dilakukan pada pelanggan produk Tupperware di Kota Denpasar. Sampel yang digunakan adalah 100 responden, dengan metode purposive sampling. Pengumpulan data menggunakan kuesioner. Teknik analisis data yang digunakan adalah analisis jalur serta uji sobel. Berdasarkan hasil analisis ditemukan bahwa green perceived value, kepuasan konsumen, serta green trust berpengaruh positif signifikan terhadap green repurchase intention, secara langsung dimana semakin tinggi green perceived value, kepuasan konsumen dan green trust akan meningkatkan green reuprchase intention pada produk tersebut. Green perceived value dan kepuasan konsumen secara tidak langsung dapat mempengaruhi green repurchase intention melalui green trust, yang artinya pengaruh green trust akan semakin besar apabila diikuti dengan peningkatan green perceived value dan kepuasan konsumen.

Kata kunci : green perceived value, kepuasan konsumen, green trust, green reuprchase intention
\end{abstract}

\begin{abstract}
Green repurchase intention is the tendency of consumers to repurchase the same environmentally friendly products in the future. The purpose of this study was to determine the effect of green perceived value, customer satisfaction, and green trust on the green repurchase intention. This research was conducted on Tupperware product customers in Denpasar. The sample used was 100 respondents, with purposive sampling method. Path analysis and sobel test were used. Based on the results of the analysis that green perceived value, customer satisfaction, and green trust have significant positive effect on green repurchase intention directly which the higher green perceived value, consumer satisfaction and green trust will increase green repurchase value on the product. Green perceived value and consumer satisfaction can indirectly affect green repurchase intention through green trust, means that the effect of green trust will be greater if followed by an increase in green perceived value and customer satisfaction.

Keywords: green perceived value, consumer satisfaction, green trust, green reuprchase
\end{abstract} intention 


\section{PENDAHULUAN}

Aktivitas manusia terutama pada bidang industri dan pertanian yang terkesan mengeksploitasi sumber daya alam secara berlebihan telah menciptakan efek gas rumah kaca dalam jumlah yang cukup besar sehingga mengakibatkan kenaikan suhu bumi (Cahyani \& Wardana, 2017). Menurut Royer et al. (2018), selain berasal dari pembakaran bahan bakar fosil dan asap industri, gas etilena dan metana yang dihasilkan dari plastik yang terkena cahaya matahari juga turut menjadi penyumbang efek gas rumah kaca. Plastik yang pada dasarnya susah terurai semakin menumpuk dan menimbulkan pencemaran yang parah akibat dari penggunaannya yang berlebihan. Berikut adalah data komposisi sampah yang terdapat di masyarakat Kota Denpasar periode tahun 2017-2018.

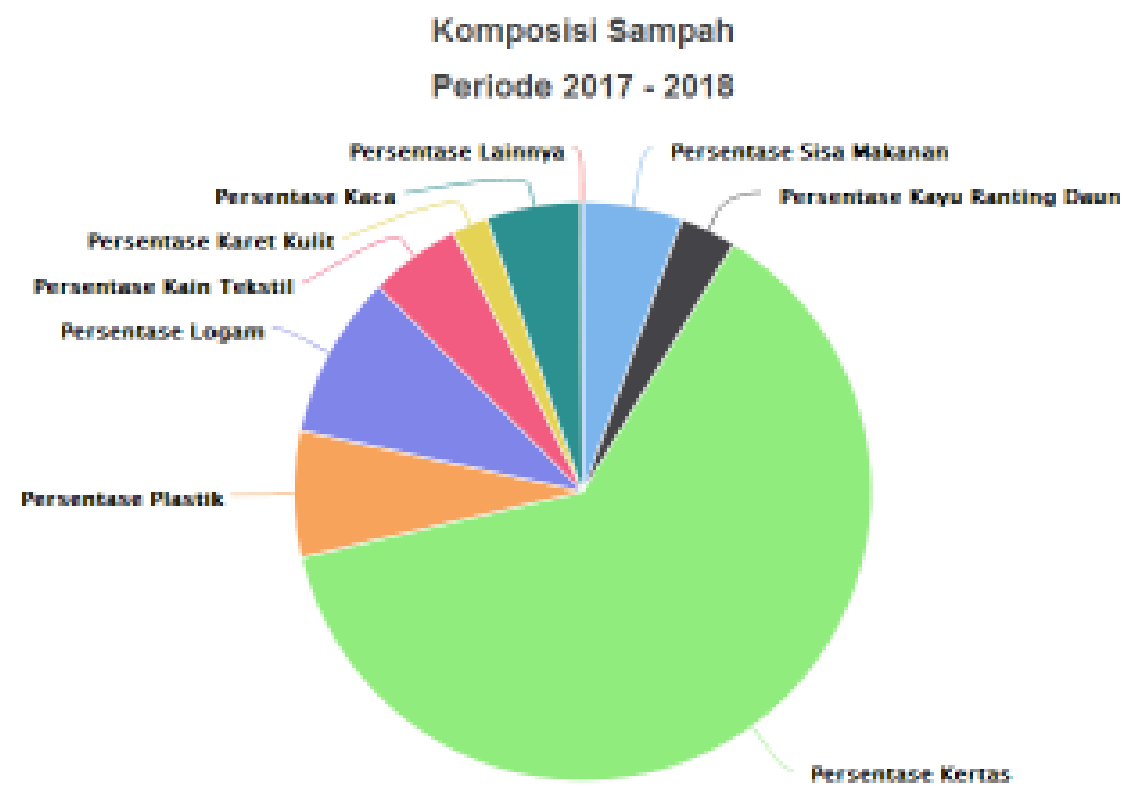

Gambar 1. Komposisi Sampah Kota Denpasar Periode 2017-2018

Sumber: Kementrian Lingkungan Hidup dan Kehutanan, 2019

Berdasarkan data dari Gambar 1. dapat dilihat bahwa persentase sampah plastik menempati posisi kedua setelah sampah kertas, dan merupakan sampah anorganik tertinggi yang dihasilkan oleh masyarkat. Falah \& Ebrahimi (2014), menunjukkan bukti-bukti dari Ilmuan dan pemerhati lingkungan, seperti lapisan ozon yang menipis, pemanasan global yang mengakibatkan iklim dunia berubah, berkembangnya penyakit yang membahayakan tubuh akibat dari penggunaan bahan-bahan sintetis dalam makanan, polusi air dan udara yang diakibatkan dari penggunaan bahan-bahan kimia yang berbahaya bagi kelangsungan hidup makhluk hidup dan lingkungannya. Jika hal ini tidak diperhatikan secara serius maka dapat dipastikan lingkungan sekitar semakin rusak karena ulah manusia itu sendiri.

Polusi udara, tanah dan air, Pemanasan global, lapizan ozon yang menipis, merupakan imbas yang harus ditanggung oleh manusia itu sendiri. Kerusakan lingkungan yang telah terjadi menyebabkan konsumen mengubah sikap dan 
perilaku mereka secara bertahap dalam hal konsumsi (Andrila \& Mousumi, 2015). Perubahan permintaan kosumen karena kesadaran akan pentingnya menjaga lingkungan, mengharuskan perusahaan tanggap dan mampu bersaing (Sari et al., 2015).

Green marketing merupakan konsep bisnis baru yang dikembangkan oleh perusahaan inovatif sebagai respon munculnya isu mengenai kerusakan (Romadon et al., 2014). Melirik pada berubahnya iklim dan gaya hidup masyarakat yang mulai peduli terhadap kerusakan lingkungan mengakibatkan green marketing diterima oleh masyarakat dengan anggapan akan membuat perubahan positif bagi lingkungan (Tariq \& Zubair, 2014). Arseculeratne \& Yazdanifard (2014), menyebutkan bahwa green marketing adalah kegiatan peluncuran dan promosi produk sehingga bisa memenuhi kebutuhan dan keinginan kosnumen tanpa merusak lingkungan. Saat ini, penerapan strategi hijau tidak hanya digunakan untuk mengejar keuntungan materi tetapi juga kepentingan sosial (Chiang et al., 2014).

Produk ramah lingkungan merupakan produk yang terdiri dari komponen yang aman, menggunakan kemasan ramah lingkungan, tidak beracun, serta dapat didaur ulang (Sarawaty \& Suprapti, 2015). Menurut Shaputra (2013) produk ramah lingkungan merupakan salah satu upaya untuk meminimalkan limbah ketika proses produksi dan harus memiliki kualitas produk tahan lama yang mana tidak gampang rusak, tidak mengandung racun, dibuat dari bahan yang dapat didaur ulang dan memiliki kemasan yang minimalis. Namun produk ramah lingkungan tidak mudah diterima oleh konsumen karena perlu diperkenalkan lebih detail terkait bagaimana performa lingkungan produk itu.

Konsumen yang menggunakan produk ramah lingkungan contohnya produk dengan potensi daur ulang dan polusi rendah, dapat menimbulkan emosi konsumen untuk menjaga serta melindungi lingkungan (Norazah \& Norbayah, 2016). Namun persepsi akan rendahnya kualitas produk serta tidak sesuai antara janji dan realisasi ramah lingkungan pada produk tersebut mampu mencederai harapan pada produk ramah lingkungan (Waskito, 2015).

Salah satu contoh produk ramah lingkungan yang banyak beredar di pasaran adalah Tupperware. Selain terbuat dari bahan-bahan yang aman bagi kesehatan dan ramah lingkungan, Tupperware juga memiliki beberapa program yang mengajak konsumen untuk lebih peduli terhadap lingkungan. Salah satunya adalah program Tupperware Green Living yang merupakan wujud kepedulian terhadap isu lingkungan, melalui pengurangan penggunaan sampah kemasan sekali pakai seperti kantong plastik, styrofoam dan botol minum kemasan sekai pakai serta bijak dalam menggunakan plastik

Selama dua puluh tujuh tahun dipasarkan di Indonesia, Tupperware berhasil menguasai pasar Indonesia hingga berhasil masuk kejajaran produk Top Brand. Berikut adalah prestasi Tupperware yang berhasil memperoleh penghargaan Top Brands Awards dari tahun 2015 sampai tahun 2018. 
Tabel 1.

Top Brand Indonesia Fase I

\begin{tabular}{lcccccc}
\hline \multirow{2}{*}{ Merek } & Tahun & Tahun & Tahun & Tahun & \multirow{2}{*}{ TOP } \\
\cline { 2 - 5 } & $\mathbf{2 0 1 5}$ & $\mathbf{2 0 1 6}$ & $\mathbf{2 0 1 7}$ & $\mathbf{2 0 1 8}$ & & \\
\hline Tupperware & $68.0 \%$ & $75.9 \%$ & $72.4 \%$ & $62.6 \%$ & TOP & \\
Lion Star & $21.6 \%$ & $17.9 \%$ & $17.3 \%$ & $24.6 \%$ & \multirow{2}{*}{ TOP } & \\
Lock \& lock & $2.7 \%$ & $2.5 \%$ & $4.2 \%$ & $2.7 \%$ & & \\
\cline { 1 - 3 } & & & & & &
\end{tabular}

Sumber : Top Brand Award Indonesia, 2018

Data tersebut menunjukkan bahwa Tupperware menjadi pilihan teratas masyarakat Indonesia dalam memilih produk rumah tangga ramah lingkungan berbahan dasar plastik. Selain itu berdasarkan hasil pra-survei yang dilakukan terhadap 20 orang responden yang pernah membeli produk Tupperware, sebesar 95.2\% menyatakan bahwa mereka berniat untuk melakukan pembelian kembali produk Tupperware karena dapat mengurangi penggunaan sampah plastik kemasan yang hanya dapat digunakan satu kali.

Tingginya market share dari pengguna produk Tupperware yang ditunjukkan oleh Tabel 1. mengindikasikan bahwa niat beli kembali konsumen terhadap produk ramah lingkungan ini cukup tinggi. Niat beli kembali diartikan sebagai perilaku konsumen yang cenderung secara berulang membeli produk barang dan jasa dan dilakukan secara berulang dalam jangka waktu tertentu, serta secara aktif mempunyai sikap positif dan menyukai menurut pengalaman sebelumnya (Suryana \& Eliyandi, 2013). Menurut Lam et al. (2016) niat beli kembali pada peoduk ramah lingkungan atau green repurchse intention dipengaruhi oleh green perceived value, kepuasan konsumen, dan green trust.

Tingginya kepercayaan atau green trust terhadap produk ramah lingkungan dipengaruhi green perceived value yang mana adalah nilai keseluruhan yang diberikan oleh konsumen terkait manfaat dan apa yang dikorbankan dari produk ramah lingkungan terkait (Chen \& Chang, 2013). Menurut penelitian sebelumnya oleh Putra \& Rastini (2017) menyatakan bahwa green perceived value memiliki pengaruh positif dan signifikan terhadap green trust. Apabila green perceived value yang dimiliki tinggi, maka green trustnya juga tinggi begitu pula sebaliknya jika green perceived value rendah, maka green trust juga rendah. Dewi \& Rastini (2016) juga menyatakan jika green trust secara signifikan menjadi pemediasi antara green perceived value dan green repurchase intention.

Akan tetap hasil yang berbeda dimuat dalam penelitian yang dilakukan Octaviany (2016) pada produk lemari es merek LG yang mendapatkan hasil bahwa green perceived value tidak berpengaruh terhadap green trust. Begitu pula dengan penelitian yang dilakukan oleh Prastiwi (2016) yang menunjukkan bahwa kepuasan konsumen tidak berpengaruh signifikan terhadap repurchase intention. Berdasarkan latar belakang yang telah dipaparkan penelitian ini memiliki tujuan untuk apakah green perceived value dan kepuasan konsumen berpengaruh terhadap green trust dan green repurchase intention, serta apakah green trust mampu memediasi green perceived value dan kepuasan konsumen terhadap green repurchase intention. 
Green perceived value merupakan nilai secara keseluruhan dari konsumen terhadap manfaat yang didapatkan dan apa yang dikorbankan menurut pada hasrat mengenai lingkungan, harapan adanya keberlanjutan, dan segala kebutuhan hijaunya (Chen \& Chang, 2012). Green perceived value juga dapat diartikan sebagi keuntungan bersih dari penilaian keseluruhan konsumen melalui evaluasi suatu produk atau jasa yang ramah lingkungan (Liang \& Chaipoopirutana, 2014)

Kepuasan didefinisikan sebagai terpenuhinya keinginan atau harapan konsumen terhadap barang atau jasa yang telah dikonsumsinya. Kepuasan yang dirasakan para konsumen setelah penggunaan produk atau jasa akan mendatangkan kepercayaan terhadap produk tersebut. Rosannah (2014), menyebutkan jika kepuasan yang dirasakan konsumen tinggi maka kepercayaan yang muncul akan tinggi pula. Adanya kepuasan konsumen yang tinggi akan berdampak pula terhadap niat membeli kembali atau repurchase intention. Menurut Dwipayana \& Sulistyawati (2018), kepercayaan dan kepuasan konsumen merupakan faktor kunci dalam membangun niat membeli ulang konsumen.

Green trust adalah sebuah keinginan untuk bergantung pada suatu produk, jasa atau merek menurut keyakinan atau harapan yang dihasilkan dari kredibilitas, perbuatan baik, serta kecakapan tentang kinerja lingkungan (Chen \& Chang, 2013). Apabila informasi yang diperoleh oleh konsumen tentang manfaat suatu produk banyak dan terperinci maka akan timbul kepercayaan terhadap produk tersebut. Kepercayaan memiliki peranan penting dalam keputusan konsumen untuk melakukan pembelian (Kaveh et al., 2012). Apabila kepercayaan konsumen terhadap suatu produk tinggi, maka kemungkinan konsumen untuk melakukan pembelian kembali juga semakin tinggi.

Green repurchase intention merupakan perilaku pembelian produk ramah lingkungan dimana konsumen merespon positif terhadap kualitas produk ramah lingkungan dan berniat untuk melakukan kunjungan kembali atau mengonsumsi kembali produk ramah lingkungan di perusahaan tersebut (Lam et al., 2016). Menurut Zhuang et al. (2010) green repurchase intention merupakan hubungan jangka panjang dengan pelanggan dari mengandalkan produk ramah lingkungan

Penelitian terdahulu yang dilakukan oleh Cahyani \& Wardana (2017) terhadap produk Ultrajaya menunjukkan adanya hubungan positif antara green perceived value dan green trust. Selain itu terdapat pula penelitian dari Pratama (2014) menunjukkan bahwa terdapat hubungan antara green perceived value terhadap green trust konsumen pada lampu Philips LED. Penelitian yang dilakukan oleh Dewi \& Rastini (2016) pada produk The Face Shop juga menunjukkan bahwa green perceived value secara positif signifikan berpengaruh terhadap green trust.

$\mathrm{H}_{1}$ : Green perceived value berpengaruh positif dan signifikan terhadap Green trust.

Menurut penelitian yang dilakukan oleh Ha et al. (2010) menunjukkan bahwa terdapat hubungan positif dan signifikan antara kepuasan konsumen terhadap kepercayaan atau trust. Rosannah (2014) mengemukakan bahwa apabila kepuasan yang dirasakan konsumen maka kepercayaan yang muncul tinggi pula. Selain itu dari hasil penelitian Masitoh \& Widikusyanto (2017) juga menyatakan 
bahwa kepuasan konsumen berpengaruh positif terhadap kepercayaan atau trust. Sehingga dengan demikian hipotesis $\mathrm{H}_{2}$ adalah sebagai berikut.

$\mathrm{H}_{2}$ : Kepuasan konsumen berpengaruh positif dan signifikan terhadap kepercayaan pada produk ramah lingkungan atau green trust.

Berdasarkan penelitian terdahulu yang dilakukan oleh Cahyani \& Wardana (2017) menunjukkan bahwa green perceived value berpengaruh positif dan signifikan terhadap green repurchase intention. Hasil penelitian yang dilakukan oleh Lam et al. (2016) juga menunjukkan bahwa green perceived value berpengaruh positif dan signifikan terhadap green repurchase intention. Penelitian serupa yang dilakukan oleh Dewi \& Rastini (2016) juga menunjukkan adanya pengaruh positif signifikan green perceived terhadap green repurchase intention.

$\mathrm{H}_{3}$ : Green perceived value berpengaruh positif dan signifikan terhadap green repurchase intention.

Fang et al. (2011) mengemukakan bahwa kepuasan konsumen paling dominan memengaruhi niat membeli kembali. Dapat dinyatakan bahwa terdapat pengaruh positif dan signifikan dari kepuasan konsumen terhadap niat membeli kembali atau repurchase intention. Penelitian dari Huang et al., (2014) menunjukkan efek positif dan signifikan dari kepuasan konsumen mempunyai terhadap niat membeli kembali. Selain itu penelitian yang dilakukan oleh Dharmayana \& Rahanatha (2017) mendapatkan hasil bahwa kepuasan konsumen secara signifikan berpengaruh terhadap niat membeli kembali.

$\mathrm{H}_{4}$ : Kepuasan konsumen berpengaruh positif dan signifikan terhadap green repurchase intention.

Penelitian yang dilakukan oleh Farida \& Elia (2015) terhadap produk Starbuck menunjukkan bahwa green trust memiliki pengaruh positif signifikan terhadap green repurchase intention. Selain itu penelitian yang dilakukan oleh Lam et al. (2016) menunjukkan bahwa green trust memiliki pengaruh positif dan signifikan terhadap green repurchase intention. Penelitian lainnya dilakukan oleh Dewi \& Rastini (2016) juga menunjukkan bahwa green trust berpengaruh positif dan signifikan terhadap green repurchase intention.

$\mathrm{H}_{5}$ : Green trust berpengaruh positif dan signifikan terhadap green repurchase intention.

Pada $\mathrm{H}_{1}$ diajukan hipotesis bahwa variabel green perceived value secara positif berhubungan dengan green repurchase intention. Pada $\mathrm{H}_{3}$ dan $\mathrm{H}_{5}$ variabel green perceived value secara positif berhubungan dengan green repurchase intentiondan variabel green trust secara positif berhubungan dengan green repurchase intention. Berdasarkan hipotesis tersebut, terdapat pengaruh tidak langsung yang positif dari variabel green perceived value terhadap green repurchase intention melalui green trust.

Hal ini juga didukung hasil penelitian dari Chen \& Chang (2012) yang menyebutkan bahwa perusahaan perlu meningkatkan green trust pelanggan karena terdapat efek mediasi positif signifikan green trust, sehingga perusahaan dapat membangun green trust dari pelanggan untuk meningkatkan tingkat positif hubungan antara green perceived value dan green repurchase intention. Penelitian dari Dewi \& Rastini (2016) juga menunjukkan bahwa green trust secara positif 
dan signifikan memediasi pengaruh green perceived value terhadap green repurchase intention pada produk The Face Shop di kota Denpasar.

$\mathrm{H}_{6}$ : Green trust secara positif dan signifikan memediasi pengaruh green perceived value terhadap green repurchase intention.

Pada $\mathrm{H}_{2}$ diajukan hipotesis bahwa variabel kepuasan konsumen secara positif berhubungan dengan green repurchase intention. Pada $\mathrm{H}_{2}$ dan $\mathrm{H}_{5}$ variabel kepuasan konsumen secara positif berhubungan dengan green repurchase intention dan variabel green trust secara positif berhubungan dengan green repurchase intention. Berdasarkan hipotesis tersebut, terdapat pengaruh tidak langsung yang positif dari variabel kepuasan konsumen terhadap green repurchase intention melalui green trust. Penelitian yang dilakukan oleh Putri \& Suparna (2014) dan Ha et al. (2010) menunjukkan bahwa trust atau kepercayaan dapat memediasi kepuasan konsumen terhadap niat membeli kembali atau green repurchase intention. Dengan demikian maka hipotesis $\mathrm{H}_{7}$ dapat dirumuskan sebagai berikut.

$\mathrm{H}_{7}$ : Green trust secara positif dan signifikan memediasi pengaruh kepuasan konsumen terhadap green repurchase intention.

\section{METODE PENELITIAN}

Penelitian ini menggunakan metode pendekatan kuantitatif dengan jenis penelitian asosiatif. Penelitian ini dilaksanakan di Kota Denpasar Adapun objek dari penelitian ini adalah perilaku konsumen khususnya green repurchase intentionyang timbul akibat dari green perceived value, kepuasan konsumen dan green trust terhadap produk ramah lingkungan Tupperware di Kota Denpasar. Variabel eksogen dalam penelitian ini adalah green perceived value yang disimbolkan oleh $\mathrm{X}_{1}$ dan kepuasan konsumen yang disimbolkan dengan $\mathrm{X}_{2}$. Variabel mediasi adalah variabel yang berperan ganda dan menjembatani hubungan antara variabel eksogen dan endogen. Variabel mediasi dalam penelitian ini adalah green trust yang disimbolkan dengan $\mathrm{Y}_{1}$. Variabel endogen dalam penelitian ini adalah green repurchase intention yang disimbolkan dengan $\mathrm{Y}_{2}$.

Data kuntitatif dalam penelitian ini berupa data sampah yang dihasilkan masyarakat, data sumber plastik sampah, serta data top brand tahun 2015- 2018 dari produk Tupperware. Data kualitatif dalam penelitian ini adalah jawaban atas kuesioner yang diberikan kepada responden. Sumber primer adalah responden yang memberikan data melalui kuesioner yang telah dibagikan. Populasi dari penelitian ini adalah konsumen yang sudah pernah membeli produk Tupperware dan berdomisili di Kota Denpasar. Teknik pengambilan sampel yang dipilih dalam penelitian ini adalah purposive sampling. Kriteria penentuan sampel daam penelitian ini adalah Sudah pernah membeli produk Tupperware. Jenjang pendidikan minimum SMA/sederajat dengan asumsi bahwa responden dengan tingkat pendidikan minimal SMA/sederajat dapat memahami dan mampu menjawab kuesioner dengan efektif. Berdomisili di Kota Denpasar. Jumlah sampel sebanyak 100 responden, dengan instrumen penelitian berupa kuesioner. 


\section{HASIL DAN PEMBAHASAN}

Karakteristik responden adalah data responden yang didapatkan langsung dari lapangan untuk mengetahui profil responden penelitian. Penelitian ini menggunakan sampel 100 konsumen. Berikut merupakan data identitas responden menurut berdasarkan usia, jenis kelamin dan pekerjaan responden. Secara rinci karakteristik responden disajikan pada Tabel 2.

Penelitian ini didominasi oleh responden dengan rentangan usia 17 - 25 diantara yang lainnya. Pada Tabel 2. dapat dilihat sebagian besar responden berjenis kelamin perempuan. Jika dilihat dari karakteristik responden pada bagian pekerjaan, responden didominasi oleh mahasiswa.

Tabel 2.

Karakteristik Responden

\begin{tabular}{|c|c|c|c|c|}
\hline No & Karakteristik & Klasifikasi & $\begin{array}{c}\text { Jumlah } \\
\text { Responden } \\
\text { (orang) }\end{array}$ & $\begin{array}{c}\text { Presentase } \\
\text { Responden } \\
(\%)\end{array}$ \\
\hline \multirow{4}{*}{1} & \multirow{3}{*}{ Usia } & 17 - 25 Tahun & 87 & 87 \\
\hline & & 26 - 30 Tahun & 13 & 13 \\
\hline & & $>30$ Tahun & 0 & 0 \\
\hline & \multicolumn{2}{|c|}{ Jumlah } & 100 & 100 \\
\hline \multirow{2}{*}{2} & \multirow{2}{*}{ Jenis Kelamin } & Laki - Laki & 23 & 23 \\
\hline & & Perempuan & 77 & 77 \\
\hline \multirow{7}{*}{3} & \multicolumn{2}{|c|}{ Jumlah } & 100 & 100 \\
\hline & \multirow{5}{*}{ Pekerjaan } & Mahasiswa & 66 & 66 \\
\hline & & Pegawai Swasta & 30 & 30 \\
\hline & & PNS & 0 & 0 \\
\hline & & Pelajar & 0 & 0 \\
\hline & & Wiraswasta & 4 & 4 \\
\hline & \multicolumn{2}{|c|}{ Jumlah } & 100 & 100 \\
\hline
\end{tabular}

Sumber : Data diolah,2019

Hasil dari uji validitas menunjukkan bahwa seluruh instrumen penelitian yang digunakan untuk mengukur variabel green perceived value, Kepuasan konsumen, green trust dan green repurchase intention memiliki nilai koefisien korelasi dengan skor total seluruh item pernyataan lebih besar dari $r$ tabel dengan signifikan 0,05 dan derajat kebebasan $n-2=100-2=98$ yakni 0,197 . Hal ini menunjukkan bahwa butir-butir pernyataan dalam instrumen penelitian tersebut valid dan layak digunakan sebagai instrumen penelitian.

Hasil uji reliabilitas menunjukkan bahwa seluruh instrumen penelitian memiliki koefisien Cronbach's Alpha lebih dari 0,6. Jadi dapat dinyatakan bahwa seluruh variabel telah memenuhi syarat reliabilitas atau kehandalan sehingga dapat digunakan untuk melakukan penelitian.

Tabel 3. menunjukkan green perceived value konsumen secara keseluruhan baik hal ini dapat dilihat dari keseluruhan rata-rata nilai $g$. Green perceived value yaitu 4,00. Nilai rata-rata tertinggi pada pernyataan "Menurut saya produk Tupperware memberikan manfaat yang lebih bagi saya jika dibandingkan dengan menggunakan kemasan plastik sekali pakai”. Hal ini menunjukan menurut 
konsumen produk Tupperware memberikan manfaat yang lebih bagi konsumen jika dibandingkan dengan menggunakan kemasan plastik sekali pakai.

Nilai rata-rata terendah terdapat pada pernyataan "Saya mengetahui program Tupperware Green Living yang diadakan oleh Tupperware sebagai wujud kepedulian terhadap lingkungan". Hal ini menunjukan bahwa tidak semua konsumen mengetahui program Tupperware Green Living yang diadakan oleh Tupperware sebagai wujud kepedulian terhadap lingkungan. Sehingga harus lebih dipromosikan kepada konsumen.

Tabel 3.

Deskripsi Jawaban Responden Terhadap Green perceived value

\begin{tabular}{|c|c|c|c|c|c|c|c|c|}
\hline \multirow{2}{*}{ No } & \multirow{2}{*}{ Pernyataan } & \multicolumn{5}{|c|}{ Frekuensi Jawaban Responden } & \multirow{2}{*}{ Rata-Rata } & \multirow{2}{*}{ Kriteria } \\
\hline & & STS & TS & $\mathbf{N}$ & $\mathbf{S}$ & SS & & \\
\hline 1 & $\begin{array}{l}\text { Menurut saya produk } \\
\text { Tupperware memberikan } \\
\text { manfaat yang lebih bagi } \\
\text { saya jika dibandingkan } \\
\text { dengan menggunakan } \\
\text { kemasan plastik sekali } \\
\text { pakai }\end{array}$ & - & - & 8 & 35 & 57 & 4,49 & $\begin{array}{c}\text { Sangat } \\
\text { Baik }\end{array}$ \\
\hline 2 & $\begin{array}{l}\text { Menurut saya produk } \\
\text { Tupperware bermanfaat } \\
\text { dalam } \\
\text { lingkungan menjaga } \\
\text { mengurangi penggunaan } \\
\text { kemasan plastik sekali } \\
\text { pakai yang dapat } \\
\text { memperparah kerusakan } \\
\text { lingkungan }\end{array}$ & - & - & 16 & 49 & 35 & 4,19 & Baik \\
\hline 3 & $\begin{array}{l}\text { Saya mengetahui program } \\
\text { Tupperware green living } \\
\text { yang diadakan oleh } \\
\text { Tupperware sebagai } \\
\text { wujud kepedulian } \\
\text { terhadap lingkungan }\end{array}$ & 6 & 11 & 28 & 51 & 4 & 3,36 & $\begin{array}{c}\text { Cukup } \\
\text { Baik }\end{array}$ \\
\hline 4 & $\begin{array}{l}\text { Kualitas yang ditawarkan } \\
\text { produk Tupperware } \\
\text { berbanding lurus dengan } \\
\text { harganya }\end{array}$ & - & 7 & 20 & 45 & 28 & 3,94 & Baik \\
\hline & Rata-rata keseluruhan var & tbel $G$ & $n P e$ & eiv & alue & & 4,00 & Baik \\
\hline
\end{tabular}

Sumber : Data diolah, 2019

Tabel 4. menunjukkan kepuasan konsumen secara keseluruhan puas hal ini dapat dilihat dari keseluruhan rata-rata nilai kepuasan konsumen yaitu 3,89. Nilai rata-rata tertinggi pada pernyataan "Saya merasa produk dari Tupperware sangat tepat digunakan untuk mengganti kemasan plastik sekali pakai". Hal ini menunjukan menurut konsumen produk dari Tupperware sangat tepat digunakan untuk mengganti kemasan plastik sekali pakai.

Nilai rata-rata terendah terdapat pada pernyataan "Saya merasa produk yang ditawarkan Tupperware sesuai dengan harapan saya". Hal ini menunjukan bahwa 
tidak semua konsumen merasa produk yang ditawarkan Tupperware sesuai dengan harapan. Terkadang ada produk yang ditawarkan diluar ekspektasi dari konsumen baik dari segi kualitas, ukuran, harga dan lain sebagainya.

Tabel 4.

Deskripsi Jawaban Responden terhadap Kepuasan Konsumen

\begin{tabular}{|c|c|c|c|c|c|c|c|c|}
\hline \multirow[t]{2}{*}{ No } & \multirow[t]{2}{*}{ Pernyataan } & \multicolumn{5}{|c|}{$\begin{array}{c}\text { Frekuensi Jawaban } \\
\text { Responden }\end{array}$} & \multirow{2}{*}{$\begin{array}{l}\text { Rata- } \\
\text { Rata }\end{array}$} & \multirow[t]{2}{*}{ Kriteria } \\
\hline & & STS & TS & $\mathbf{N}$ & $\mathbf{S}$ & SS & & \\
\hline 1 & $\begin{array}{l}\text { Saya merasa puas dengan } \\
\text { kinerja dari produk } \\
\text { Tupperware }\end{array}$ & - & 3 & 23 & 42 & 32 & 4,03 & Puas \\
\hline 2 & $\begin{array}{l}\text { Saya merasa produk yang } \\
\text { ditawarkan Tupperware sesuai } \\
\text { dengan harapan saya }\end{array}$ & - & 12 & 43 & 28 & 17 & 3,50 & Puas \\
\hline 3 & $\begin{array}{l}\text { Saya merasa produk dari } \\
\text { Tupperware sangat tepat } \\
\text { digunakan untuk mengganti } \\
\text { kemasan plastik sekali pakai }\end{array}$ & - & 2 & 22 & 36 & 40 & 4,14 & Puas \\
\hline \multicolumn{7}{|c|}{ Rata-rata keseluruhan variabel Kepuasan Konsumen } & 3,89 & Puas \\
\hline
\end{tabular}

Tabel 5.

Deskripsi Jawaban Responden Terhadap Variabel Green trust

\begin{tabular}{|c|c|c|c|c|c|c|c|c|}
\hline \multirow[t]{2}{*}{$\begin{array}{l}\mathbf{N} \\
\mathbf{0}\end{array}$} & \multirow[t]{2}{*}{ Pernyataan } & \multicolumn{5}{|c|}{$\begin{array}{c}\text { Frekuensi Jawaban } \\
\text { Responden }\end{array}$} & \multirow{2}{*}{$\begin{array}{l}\text { Rata- } \\
\text { Rata }\end{array}$} & \multirow[t]{2}{*}{ Kriteria } \\
\hline & & STS & TS & $\mathbf{N}$ & $\mathbf{S}$ & SS & & \\
\hline 1 & $\begin{array}{l}\text { Saya yakin bahwa produk } \\
\text { yang ditawarkan Tupperware } \\
\text { adalah produk ramah } \\
\text { lingkungan yang berfungsi } \\
\text { untuk mengurangi penggunaan } \\
\text { kemasan plastik sekali pakai }\end{array}$ & - & - & 3 & 22 & 75 & 4,72 & $\begin{array}{l}\text { Sangat } \\
\text { Baik }\end{array}$ \\
\hline 2 & $\begin{array}{l}\text { Saya mengenal produk } \\
\text { Tupperware sebagai produk } \\
\text { ramah lingkungan yang } \\
\text { termasuk kategori top brand }\end{array}$ & 1 & 5 & 20 & 59 & 15 & 3,82 & Baik \\
\hline 3 & $\begin{array}{l}\text { Saya percaya produk dari } \\
\text { Tupperware memiliki kinerja } \\
\text { yang baik dalam turut menjaga } \\
\text { lingkungan }\end{array}$ & - & 3 & 20 & 32 & 45 & 4,19 & Baik \\
\hline 4 & $\begin{array}{l}\text { Kedepannya saya yakin } \\
\text { Tupperware akan menjaga } \\
\text { serta menghasilkan produk } \\
\text { yang lebih baik dari } \\
\text { sebelumnya }\end{array}$ & - & 1 & 14 & 51 & 34 & 4,18 & Baik \\
\hline & Rata-rata keseluruhan & iabel & 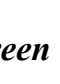 & ust & & 4,23 & $\begin{array}{c}\text { Sangat } \\
\text { Baik }\end{array}$ & Tinggi \\
\hline
\end{tabular}

Sumber : Data diolah, 2019

Tabel 5. menunjukkan secara keseluruhan rata-rata jawaban responden terhadap variabel green trust memiliki nilai sebesar 4,23. Hasil penyebaran 
kuisioner menunjukkan bahwa pernyataan "Saya yakin bahwa produk yang ditawarkan Tupperware adalah produk ramah lingkungan yang berfungsi untuk mengurangi penggunaan kemasan plastik sekali pakai" memiliki nilai rata-rata paling tinggi, hal ini berarti konsumen yakin bahwa produk yang ditawarkan Tupperware adalah produk ramah lingkungan yang berfungsi untuk mengurangi penggunaan kemasan plastik sekali pakai.

Nilai rata-rata terendah terdapat pada pernyataan "Saya mengenal produk Tupperware sebagai produk ramah lingkungan yang termasuk kategori top brand ". Hal ini menunjukan bahwa konsumen belum mengenal produk Tupperware sebagai produk ramah lingkungan yang termasuk kategori top brand. Sehingga perlunya lebih promosi agar merek Tupperware semakin terkenal sebagai produk ramah lingkungan.

Tabel 6.

Deskripsi Jawaban Responden Variabel Green repurchase intention

\begin{tabular}{|c|c|c|c|c|c|c|c|c|}
\hline \multirow{2}{*}{ No } & \multirow{2}{*}{ Pernyataan } & \multicolumn{5}{|c|}{ FrekuensiJawaban Responden } & \multirow{2}{*}{ Rata-Rata } & \multirow{2}{*}{ Kriteria } \\
\hline & & STS & TS & $\mathbf{N}$ & $\mathbf{S}$ & SS & & \\
\hline 1 & $\begin{array}{l}\text { Saya berniat membeli } \\
\text { kembali produk dari } \\
\text { Tupperware }\end{array}$ & - & - & 22 & 37 & 41 & 4,19 & Baik \\
\hline 2 & $\begin{array}{l}\text { Saya tertarik untuk mencari } \\
\text { informasi lebih lanjut } \\
\text { mengenai keunggulan } \\
\text { Tupperware sebagi produk } \\
\text { ramah lingkungan }\end{array}$ & - & 5 & 22 & 36 & 37 & 4,05 & Baik \\
\hline 3 & $\begin{array}{l}\text { Apabila diminta untuk } \\
\text { memilih produk ramah } \\
\text { lingkungan untuk tempat } \\
\text { makan atau minum } \\
\text { Tupperware selalu menjadi } \\
\text { pilihan utama saya }\end{array}$ & - & 3 & 20 & 34 & 43 & 4,17 & Baik \\
\hline 4 & $\begin{array}{l}\text { Saya merekomendasikan } \\
\text { produk Tupperware kepada } \\
\text { teman-teman saya agar turut } \\
\text { serta mengurangi } \\
\text { penggunaan kemasan plastik } \\
\text { sekali pakai dalam industri } \\
\text { makanan }\end{array}$ & - & 2 & 24 & 30 & 44 & 4,16 & Baik \\
\hline 5 & $\begin{array}{l}\text { Saya selalu mengantisipasi } \\
\text { produk-produk terbaru yang } \\
\text { akan dilucurkan oleh } \\
\text { Tupperware }\end{array}$ & 2 & 7 & 31 & 36 & 24 & 3,73 & Baik \\
\hline & Rata-rata keseluruhan vari & el Gre & $\operatorname{Rep}$ & cha & nes & & 4,06 & Baik \\
\hline
\end{tabular}

Sumber : Data diolah, 2019

Tabel 6. menunjukkan secara keseluruhan rata-rata jawaban responden terhadap variabel green repurchase intention memiliki nilai sebesar 4,06. Hasil penyebaran kuisioner menunjukkan bahwa green repurchase intentionperusahaan baik. Nilai rata-rata tertinggi terdapat pada pernyataan "Saya berniat membeli kembali produk dari Tupperware". Hal ini menunjukan bahwa konsumen berniat membeli kembali produk dari Tupperware. 
Nilai rata-rata terendah terdapat pada pernyataan "Saya selalu mengantisipasi produk-produk terbaru yang akan dilucurkan oleh Tupperware".

Hal ini menunjukkan bahwa konsumen tidak selalu mengantisipasi produkproduk terbaru yang akan dilucurkan oleh Tupperware. Hal ini dikarenakan dominan konsumen tidak mengetahui kapan peluncuran produk baru dari Tupperware.

Tabel 7.

Hasil Uji Normalitas Model Struktur 1

\begin{tabular}{lc}
\hline & Unstandardized Residual \\
\hline $\mathrm{N}$ & 100 \\
Kolmogorov-Smirnov & 0,055 \\
Asymp Sig (2-tailed) & 0,200 \\
\hline Sumber : Data diolah,2019
\end{tabular}

Berdasarkan Tabel 7. dapat dilihat bahwa nilai Kolmogorov Sminarnov (KS) sebesar 0,055 dan nilai Asymp Sig (2-tailed) sebesar 0,200, hasil tersebut mengindikasikan bahwa model persamaan regresi tersebut berdistribusi normal karena nilai Asymp Sig (2-tailed) lebih besar dari nilai alpha 0,05.

Tabel 8.

Hasil Uji Normalitas Model Struktur 2

\begin{tabular}{lc}
\hline & Unstandardized Residual \\
\hline $\mathrm{N}$ & 100 \\
Kolmogorov-Smirnov & 0,079 \\
Asymp Sig (2-tailed) & 0,128 \\
\hline Sumber : Data diolah, 2019
\end{tabular}

Berdasarkan Tabel 8. dapat dilihat bahwa nilai Kolmogorov Sminarnov (KS) sebesar 0,079 dan nilai Asymp Sig (2-tailed) sebesar 0,128, hasil tersebut mengindikasikan bahwa model persamaan regresi tersebut berdistribusi normal karena nilai Asymp Sig(2-tailed) lebih besar dari nilai alpha 0,05.

Tabel 9.

Hasil Uji Multikoleniaritas

\begin{tabular}{clcc}
\hline Persamaan Struktur & \multicolumn{1}{c}{ Variabel } & $\begin{array}{c}\text { Tolera } \\
\text { nce }\end{array}$ & VIF \\
\hline $\mathrm{Y}_{1}=\beta_{1} \mathrm{X}_{1}+\beta_{2} \mathrm{X}_{2}+\mathrm{e}_{1}$ & Green Perceived Value $\left(\mathrm{X}_{1}\right)$ & 0,572 & 1,748 \\
& Kepuasan Konsumen $\left(\mathrm{X}_{2}\right)$ & 0,572 & 1,748 \\
$\mathrm{Y}_{2}=\beta_{3} \mathrm{X}_{1}+\beta_{4} \mathrm{X}_{2}+\beta_{5} \mathrm{Y}_{1}+\mathrm{e}_{2}$ & Green Perceived Value $\left(\mathrm{X}_{1}\right)$ & 0,772 & 1,296 \\
& Kepuasan Konsumen $\left(\mathrm{X}_{2}\right)$ & 0,455 & 2,199 \\
& Green Trust $\left(\mathrm{Y}_{1}\right)$ & 0,469 & 2,130 \\
\hline
\end{tabular}

Sumber : Data diolah, 2019

Berdasarkan Tabel 9. dapat dilihat bahwa nilai tolerance dan VIF dari variabel green perceived value, Kepuasan konsumen dan green trust menunjukkan nilai tolerance untuk setiap variabel lebih besar dari $10 \%(0,1)$ dan nilai VIF lebih kecil dari 10 yang berarti model persamaan regresi bebas dari multikolinearitas. 
Tabel 10.

Hasil Uji Heteroskedastisitas Model Struktur 1

\begin{tabular}{|c|c|c|c|c|c|c|}
\hline & \multicolumn{5}{|c|}{ Coefficients $^{\mathrm{a}}$} & \multirow{3}{*}{ Sig. } \\
\hline \multirow[t]{2}{*}{ Model } & \multicolumn{2}{|c|}{ Unstandardized Coefficients } & \multicolumn{2}{|c|}{$\begin{array}{l}\text { Standardized } \\
\text { Coefficients }\end{array}$} & \multirow[t]{2}{*}{$\mathbf{t}$} & \\
\hline & B & Std. & & & & \\
\hline \multirow[t]{3}{*}{1} & (Constant) & 3.036 & .570 & & 5.326 & .000 \\
\hline & $\begin{array}{l}\text { Green Perceived } \\
\text { Value }\end{array}$ & -.058 & .045 & -.164 & -1.285 & .202 \\
\hline & Kepuasan Konsumen & -.070 & .053 & -.169 & -1.325 & .188 \\
\hline
\end{tabular}

Pada Tabel 10. dapat dilihat bahwa nilai signifikansi dari variabel green perceived value sebesar 0,202. Nilai signifikansi dari variabel Kepuasan Konsumen sebesar 0,188. Nilai tersebut lebih besar dari 0,05 yang berarti tidak terdapat pengaruh antara variabel bebas terhadap absolute residual. Dengan demikian, model yang dibuat tidak mengandung gejala heteroskedastisitas.

Tabel 11.

Hasil Uji Heteroskedastisitas Model Struktur 2

\begin{tabular}{llrrrrr}
\hline Model & \multicolumn{2}{c}{$\begin{array}{c}\text { Unstandardized } \\
\text { Coefficients }\end{array}$} & \multicolumn{2}{c}{$\begin{array}{c}\text { Standardized } \\
\text { Coefficients }\end{array}$} & t & Sig. \\
\cline { 3 - 5 } & \multicolumn{1}{c}{ B } & Std. Error & \multicolumn{1}{c}{ Beta } & & \\
\hline 1 & (Constant) & 1.691 & .526 & & 3.214 & .002 \\
& Green Perceived Value & -.053 & .037 & -.205 & -1.456 & .149 \\
& Kepuasan Konsumen & .055 & .046 & .178 & 1.205 & .231 \\
& Green Trust & -.036 & .044 & -.121 & -.834 & .407 \\
\hline
\end{tabular}

Sumber : Data diolah,2019

Pada Tabel 11. dapat dilihat bahwa nilai signifikansi dari variabel green perceived value sebesar 0,149. Nilai signifikan dari variabel kepuasan konsumen sebesar 0,231 dan nilai signifikan variabel green trust sebesar 0,407. Nilai tersebut lebih besar dari 0,05 yang berarti tidak terdapat pengaruh antara variabel bebas terhadap absolute residual. Dengan demikian model yang dibuat tidak mengandung gejala heteroskedastisitas.

Berdasarkan hasil analisis jalur model 1, dapat dibuat persamaan struktural $\mathrm{Y}_{1}=0,339 \mathrm{X} 1+0,460 \mathrm{X} 2+0,847$.

Nilai koefisien regresi variabel green perceived value dan kepuasan konsumen bernilai positif dengan nilai signifikansi uji t kurang dari 0,05 . Hal ini menunjukkan bahwa variabel green perceived value dan kepuasan konsumen memiliki pengaruh positif yang signifikan terhadap variabel green trust. Nilai determinasi total sebesar 0,531 mempunyai arti bahwa sebesar 53,1\% variasi green trust dipengaruhi oleh variasi green perceived value dan kepuasan konsumen, sedangkan sisanya sebesar $46,9 \%$ dijelaskan oleh faktor lain yang tidak dimasukkan ke dalam model.

Tabel 12.

Hasil Analisis Jalur Model 1 


\begin{tabular}{|c|c|c|c|c|c|}
\hline \multirow[t]{2}{*}{ Variabel } & \multicolumn{2}{|c|}{$\begin{array}{c}\text { Unstandardized } \\
\text { Coefficients }\end{array}$} & \multirow[t]{2}{*}{$\begin{array}{c}\text { Standardized } \\
\text { Coefficients }\end{array}$} & \multirow{2}{*}{$\begin{array}{c}\mathbf{t} \\
\text { hitung }\end{array}$} & \multirow{2}{*}{$\underset{t}{\text { Sig. uji }}$} \\
\hline & B & Std. Error & & & \\
\hline (Constant) & 6.689 & 1.015 & & 6.593 & .000 \\
\hline $\begin{array}{l}\text { Green Perceived Value } \\
\left(\mathrm{X}_{1}\right)\end{array}$ & .294 & .080 & .339 & 3.681 & .000 \\
\hline $\begin{array}{l}\text { Kepuasan Konsumen } \\
\left(\mathrm{X}_{2}\right)\end{array}$ & .474 & .095 & .460 & 5.007 & .000 \\
\hline R Square & 0,531 & & & & \\
\hline F Statistik & 54,811 & & & & \\
\hline Signifikansi Uji F & 0,000 & & & & \\
\hline
\end{tabular}

Tabel 13.

Hasil Analisis Jalur Model 2

\begin{tabular}{|c|c|c|c|c|c|}
\hline \multirow[t]{2}{*}{ Variabel } & \multicolumn{2}{|c|}{$\begin{array}{l}\text { Unstandardized } \\
\text { Coefficients }\end{array}$} & \multirow{2}{*}{$\begin{array}{c}\text { Standardized } \\
\text { Coefficients } \\
\text { Beta } \\
\end{array}$} & \multirow{2}{*}{$\begin{array}{c}\mathbf{t} \\
\text { hitung }\end{array}$} & \multirow{2}{*}{$\begin{array}{l}\text { Sig. } \\
\text { uji t }\end{array}$} \\
\hline & B & Std. Error & & & \\
\hline (Constant) & .782 & .853 & & .917 & .361 \\
\hline $\begin{array}{l}\text { Green Perceived Value } \\
\left(\mathrm{X}_{1}\right)\end{array}$ & .528 & .059 & .442 & 8.869 & .000 \\
\hline $\begin{array}{l}\text { Kepuasan Konsumen } \\
\left(\mathrm{X}_{2}\right)\end{array}$ & .666 & .074 & .470 & 8.982 & .000 \\
\hline Green Trust $\left(\mathrm{Y}_{1}\right)$ & .196 & .071 & .142 & 2.764 & .007 \\
\hline R Square & 0,880 & & & & \\
\hline F Statistik & 235,432 & & & & \\
\hline Signifikansi Uji F & 0,000 & & & & \\
\hline
\end{tabular}

Berdasarkan hasil analisis jalur model 2 seperti yang disajikan pada Tabel 13. maka dapat dibuat persamaan struktural sebagai berikut :

$\mathrm{Y}_{2}=0,442 \mathrm{X}_{1}+0,470 \mathrm{X}_{2}+0,142 \mathrm{Y}_{1}+0,475$

Nilai koefisien regresi variabel green perceived value, Kepuasan Konsumen dan green trust bernilai positif dengan nilai signifikansi uji t kurang dari 0,05. Hal ini menunjukkan bahwa variabel green perceived value, kepuasan konsumen dan green trust memiliki pengaruh positif yang signifikan terhadap variabel green repurchase intention. Besarnya pengaruh variabel bebas terhadap variabel terikat yang ditunjukkan oleh nilai determinasi total (R Square) sebesar 0,880 mempunyai arti bahwa sebesar $88,0 \%$ variasi green repurchase intentiondipengaruhi oleh variasi green perceived value, Kepuasan Konsumen dan green trust, sedangkan sisanya sebesar $12,0 \%$ dijelaskan oleh faktor lain yang tidak dimasukkan ke dalam model.

Berdasarkan model 1 dan model 2, maka dapat disusun model diagram jalur akhir. Sebelum menyusun model diagram jalur akhir, terlebih dahulu dihitung nilai standar eror sebagai berikut:

$$
\begin{aligned}
& \text { Pei }=\sqrt{1-\mathrm{R}_{\mathrm{I}}^{2}} \\
& \mathrm{Pe} 1=\sqrt{1-R_{1}{ }^{2}}=\sqrt{1-0,531 \times 0,531}=0,847 \\
& \operatorname{Pe} 2=\sqrt{1-R_{2}^{2}} \\
& =\sqrt{1-0,880 \times 0,880}=0,475
\end{aligned}
$$


Berdasarkan perhitungan pengaruh error $\left(\mathrm{P}_{\mathrm{e} 1}\right)$, didapatkan hasil pengaruh error (Pe1) sebesar 0,847 dan pengaruh error $\left(\mathrm{P}_{\mathrm{e} 2}\right)$ sebesar 0,475. Hasil koefisien determinasi total adalah sebagai berikut :

$$
\begin{aligned}
\mathrm{R}_{\mathrm{m}}^{2} & =1-\left(\mathrm{Pe}_{1}\right)^{2}\left(\mathrm{Pe}_{2}\right)^{2} \ldots \ldots \ldots \\
& =1-(0,847)^{2}(0,475)^{2} \\
& =1-(0,717)(0,226) \\
& =1-0,162=0,838
\end{aligned}
$$

Nilai determinasi total sebesar 0,838 mempunyai arti bahwa sebesar $83,8 \%$ variasi green repurchase intention dipengaruhi oleh variasi green perceived value, kepuasan konsumen dan green trust, sedangkan sisanya sebesar 16,2\% dijelaskan oleh faktor lain yang tidak dimasukkan ke dalam model.

Berdasarkan hasil analisis pengaruh green perceived value terhadap Green trust diperoleh nilai signifikansi sebesar 0,000 dengan nilai koefisien Beta 0,339 bernilai positif. Nilai signifikansi $0,000<0,05$ mengindikasikan bahwa $\mathrm{H}_{0}$ ditolak dan $\mathrm{H}_{1}$ diterima. Hasil ini mempunyai arti bahwa green perceived value berpengaruh positif signifikan terhadap green trust.

Berdasarkan hasil analisis pengaruh kepuasan konsumen terhadap green trust diperoleh nilai signifikansi sebesar 0,000 dengan nilai koefisien beta 0,460 bernilai positif. Nilai signifikansi $0,000<0,05$ mengindikasikan bahwa $\mathrm{H}_{0}$ ditolak dan $\mathrm{H}_{2}$ diterima. Hasil ini mempunyai arti bahwa Kepuasan konsumen berpengaruh positif signifikan terhadap green trust.

Berdasarkan hasil analisis pengaruh Green perceived value terhadap green repurchase intention diperoleh nilai nignifikansi sebesar 0,000 dengan nilai koefisien beta 0,442 bernilai positif. Nilai signifikansi $0,000<0,05$ mengindikasikan bahwa $\mathrm{H}_{0}$ ditolak dan $\mathrm{H}_{3}$ diterima. Hasil ini mempunyai arti bahwa green perceived value berpengaruh positif signifikan terhadap green repurchase intention. Berdasarkan hasil analisis pengaruh kepuasan konsumen terhadap green repurchase intentiondiperoleh nilai signifikansi sebesar 0,000 dengan nilai koefisien Beta 0,470 bernilai positif.

Nilai signifikansi $0,000<0,05$ mengindikasikan bahwa $\mathrm{H}_{0}$ ditolak dan $\mathrm{H}_{4}$ diterima. Hasil ini mempunyai arti bahwa Kepuasan konsumen berpengaruh positif signifikan terhadap green repurchase intention.

Berdasarkan hasil analisis pengaruh green trust terhadap green repurchase intention diperoleh nilai signifikansi sebesar 0,007 dengan nilai koefisien beta 0,142 bernilai positif. Nilai signifikansi $0,007<0,05$ mengindikasikan bahwa $\mathrm{H}_{0}$ ditolak dan $\mathrm{H}_{5}$ diterima. Hasil ini mempunyai arti bahwa green trust berpengaruh positif signifikan terhadap green repurchase intention.

Tabel 14. menunjukkan bahwa pengaruh langsung green perceived value terhadap green trust adalah sebesar 0,339. Pengaruh langsung variabel green perceived value terhadap green repurchase intention sebesar 0,442 .

Pengaruh langsung variabel green trust terhadap green repurchase intention sebesar 0,142. Hal ini berarti bahwa variabel green repurchase intentionlebih besar dipengaruhi green perceived value daripada green trust. Sedangkan 
pengaruh tidak langsung variabel green perceived value terhadap green repurchase intention melalui green trust sebesar 0,048 . Pengaruh total variabel green perceived value terhadap green repurchase intention melalui Green trust adalah sebesar 0,490. Jadi dapat disimpulkan bahwa lebih besar total pengaruh green perceived value terhadap green repurchase intention yang melalui green trust daripada pengaruh langsung green perceived value terhadap green repurchase intention tanpa melalui variable green trust.

Tabel 14.

Pengaruh variabel Green perceived value $\left(\mathrm{X}_{1}\right)$ terhadap Green repurchase intention $\left(\mathrm{Y}_{2}\right)$ dengan Green trust $\left(\mathrm{Y}_{1}\right)$

\begin{tabular}{cccc}
\hline Pengaruh Variabel & $\begin{array}{c}\text { Pengaruh } \\
\text { Langsung }\end{array}$ & $\begin{array}{c}\text { Pengaruh Tidak } \\
\text { Langsung }\end{array}$ & Pengaruh Total \\
\hline $\mathrm{X}_{1} \rightarrow \mathrm{Y}_{1}$ & 0,339 & - & 0,339 \\
$\mathrm{X}_{1} \rightarrow \mathrm{Y}_{2}$ & 0,442 & 0,048 & 0,490 \\
$\mathrm{Y}_{1} \rightarrow \mathrm{Y}_{2}$ & 0,142 & - & 0,142 \\
\hline
\end{tabular}

Sumber : Data diolah, 2019

Tabel 15.

Pengaruh Variabel Kepuasan Konsumen (X2) terhadap Green repurchase intention(Y2) dengan Green trust (Y1)

\begin{tabular}{crcc}
\hline Pengaruh Variabel & $\begin{array}{r}\text { Pengaruh } \\
\text { Langsung }\end{array}$ & $\begin{array}{c}\text { Pengaruh Tidak } \\
\text { Langsung }\end{array}$ & Pengaruh Total \\
\hline $\mathrm{X}_{2} \rightarrow \mathrm{Y}_{1}$ & 0,460 & - & 0,460 \\
$\mathrm{X}_{2} \rightarrow \mathrm{Y}_{2}$ & 0,470 & 0,065 & 0,535 \\
$\mathrm{Y}_{1} \rightarrow \mathrm{Y}_{2}$ & 0,142 & - & 0,142 \\
\hline
\end{tabular}

Sumber: Data diolah, 2019

Tabel 15. menunjukkan bahwa pengaruh langsung kepuasan konsumen terhadap green trust adalah sebesar 0,460. Pengaruh langsung variabel kepuasan konsumen terhadap green repurchase intention sebesar 0,470. Pengaruh langsung variabel green trust terhadap green repurchase intention sebesar 0,142 . Hal ini berarti bahwa variabel green repurchase intention lebih besar dipengaruhi kepuasan konsumen dari pada green trust. Sedangkan pengaruh tidak langsung variabel kepuasan konsumen terhadap green repurchase intention melalui green trust sebesar 0,065. Jadi pengaruh total variabel kepuasan konsumen terhadap green repurchase intention melalui green trust adalah sebesar 0,535. Jadi dapat disimpulkan bahwa lebih besar total pengaruh kepuasan konsumen terhadap green repurchase intention yang melalui green trust, daripada pengaruh langsung kepuasan konsumen terhadap green repurchase intention tanpa melalui variabel green trust.

Untuk menguji signifikansi pengaruh tidak langsung maka nilai t hitung dari koefisien ab dihitung dengan rumus sebagai berikut: 
$S_{a b}=\sqrt{(0,142)^{2}(0,847)^{2}+(0,339)^{2}(0,475)^{2}+(0,847)^{2}(0,475)^{2}}$

$S_{a b}=0,005$

Untuk menguji signifikansi pengaruh tidak langsung maka menghitung nilai thitung dari koefisien ab dengan rumus sebagai berikut :

thitung $=\frac{a b}{S a b} \ldots$

thitung $=\frac{(0,339)(0,142)}{0,005}$

$t$ hitung $=\frac{(0,048)}{0,005}$

thitung $=9,628$

Oleh karena t hitung sebesar 9,628 $>1,96$. Artinya green trust secara positif dan signifikan memediasi pengaruh green perceived value terhadap green repurchase intention.

Untuk menguji signifikansi pengaruh tidak langsung maka nilai t hitung dari koefisien ab dihitung dengan rumus sebagai berikut:

$S_{a b}=\sqrt{(0,142)^{2}(0,847)^{2}+(0,460)^{2}(0,475)^{2}+(0,847)^{2}(0,475)^{2}}$

$S_{a b}=0,006$

Untuk menguji signifikansi pengaruh tidak langsung maka menghitung nilai thitung dari koefisien ab dengan rumus sebagai berikut :

thitung $=\frac{a b}{S a b}$

thitung $=\frac{(0,460)(0,142)}{0,006}$

t hitung $=\frac{(0,065)}{0,006}$

thitung $=10,886$

Oleh karena $\mathrm{t}$ hitung sebesar $10,886>1,96$. Artinya green trust secara positif dan signifikan memediasi pengaruh kepuasan konsumen terhadap Green repurchase intention.

VAF menjadi ukuran seberapa besar variabel pemediasi mampu menyerap pengaruh langsung yang sebelumnya signifikan dari model tanpa pemediasi. VAF dapat dihitung dengan $(\mathrm{b} \times \mathrm{c}) /(\mathrm{a}+\mathrm{b} \times \mathrm{c})$. Apabila nilai VAF di atas 80 persen, maka menunjukkan peran $\mathrm{Y}_{1}$ sebagai pemediasi penuh (full mediation). Selanjutnya apabila nilai VAF di antara 20 persen hingga 80 persen, maka dapat dikategorikan sebagai pemediasi parsial (partial mediation). Namun, apabila nilai VAF kurang dari 20 persen, maka dapat dijelaskan bahwa hampir tidak ada efek mediasi.

$$
\begin{aligned}
\mathrm{VAF} & =(0,142 \times 0,442) /(0,339+0,142 \times 0,442) \\
& =0,063 / 0,302 \\
& =0,209 \text { atau } 20,9 \text { persen. }
\end{aligned}
$$


Karena nilai VAF (20,9 persen) lebih dari 20 persen, maka dapat dijelaskan bahwa ada efek mediasi atau dengan kata lain green trust sebagai pemediasi parsial (partial mediation).

$$
\begin{aligned}
\mathrm{VAF} & =(0,142 \times 0,470) /(0,460+0,142 \times 0,470) \\
& =0,067 / 0,326 \\
& =0,206 \text { atau } 20,6 \text { persen. }
\end{aligned}
$$

Karena nilai VAF (20,6 persen) lebih dari 20 persen, maka dapat dijelaskan bahwa ada efek mediasi atau dengan kata lain green trust sebagai pemediasi parsial (partial mediation).

Tujuan utama dari penelitian ini adalah untuk menguji pengaruh green perceived value terhadap green trust. Hasil estimasi model struktural pada Tabel 14. menunjukkan bahwa pengujian terhadap hipotesis pertama menunjukkan signifikasi hubungan antara green perceived value dan green trust. Pengujian menunjukkan hasil bahwa keofisien beta sebesar 0,339 bernilai positif. Nilai signifikansi $0,000<0,05$ mengindikasikan bahwa $\mathrm{H}_{0}$ ditolak dan $\mathrm{H}_{1}$ diterima. Hasil ini mempunyai arti bahwa green perceived value berpengaruh positif signifikan terhadap green trust. Hal ini menunjukkan bahwa semakin tinggi green perceived value dari konsumen, maka semakin tinggi pula kepercayaan konsumen terhadap produk Tupperware di Kota Denpasar. Hasil penelitian ini sejalan dengan penelitian terdahulu yang dilakukan oleh Cahyani \& Wardana (2017) yang mengungkapkan bahwa terdapat hubungan positif dan signifikan antara green perceived value dan green trust. green perceived value yang tinggi secara langsung akan mengakibatkan tingginya kepercayaan atau green trust konsumen terhadap produk tersebut (Pratama, 2014). Selain itu penelitian yang dilakukan oleh Dewi \& Rastini (2016) terhadap produk The Body Shop juga menunjukkan bahwa green perceived value secara positif signifikan berpengaruh terhadap green trust.

Selanjutnya dalam penelitian ini bertujuan untuk menguji pengaruh kepuasan konsumen terhadap green tust. Hasil estimasi pada Tabel 15. menunjukkan bahwa pengujian terhadap hipotesis kedua menunjukkan signifikasi hubungan antara kepuasan konsumen dan green trust. Pengujian menunjukkan hasil bahwa koefisien beta sebesar 0,460 bernilai positif. Nilai signifikansi 0,000 $<0,05$ mengindikasikan bahwa $\mathrm{H}_{0}$ ditolak dan $\mathrm{H}_{2}$ diterima. Hasil ini mempunyai arti bahwa kepuasan konsumen berpengaruh positif dan signifikan terhadap green trust. Hal ini menunjukkan bahwa adanya kepuasan yang tinggi dari konsumen akan menyebabkan konsumen semakin percaya terhadap produk-produk dari Tupperware.

Hasil penelitian ini menunjukkan hasil yang sejalan dengan penelitian yang pernah dilakukan oleh oleh $\mathrm{Ha}$ et al. (2010) menunjukkan bahwa terdapat hubungan positif dan signifikan antara kepuasan konsumen terhadap kepercayaan atau trust. Rosannah (2014) mengemukakan bahwa semakin tinggi kepuasan yang dirasakan konsumen maka akan memunculkan kepercayaan yang tinggi pula pada merek tersebut. Selain itu dari hasil penelitian Masitoh \& Widikusyanto (2017) juga menyatakan bahwa kepuasan konsumen berpengaruh positif terhadap 
kepercayaan atau trust. Tujuan ketiga dari penelitian ini adalah untuk menguji pengaruh antara green perceived value terhadap green repurchase intention. Hasil estimasi pada Tabel 14. menunjukkan bahwa pengujian terhadap hipotesis ketiga menunjukkan signifikasi hubungan antara green perceived value dan green repurchase intention. Pengujian menunjukkan hasil bahwa keofisien beta sebesar 0,442 bernilai positif. Nilai signifikansi $0,000<0,05$ mengindikasikan bahwa $\mathrm{H}_{0}$ ditolak dan $\mathrm{H}_{3}$ diterima. Hasil ini mempunyai arti bahwa green perceived value berpengaruh positif dan signifikan terhadap green repurchase intention. Hal ini menunjukkan bahwa green perceived value yang tinggi dari konsumen akan menyebabkan konsumen melakukan pembelian kembali atau green repurchase intention terhadap produk-produk dari Tupperware.

Hal ini menunjukkan hasil yang sejalan dengan penelitian terdahulu yang dilakukan oleh Cahyani \& Wardana (2017) menunjukkan bahwa green perceived value berpengaruh positif dan signifikan terhadap green repurchase intention. Hasil penelitian yang dilakukan oleh Lam et al. (2016) juga menunjukkan bahwa green perceived value berpengaruh positif dan signifikan terhadap green repurchase intention. Tingginya green perceived value yang dimiliki oleh konsumen terhadapa produk akan menyebabkan konsumen melakukan pembelian ulang terhadap produk tersebut (Dewi \& Rastini, 2016). Sehingga dapat dinyatakan bahwa green perceived value memiliki pengaruh yang positif dan signifikan terhadap green repurchase intention. Tujuan selanjutnya dari penelitian ini adalah untuk menguji pengaruh antara kepuasan konsumen terhadap green repurchase intention. Hasil estimasi pada Tabel 15. menunjukkan bahwa pengujian terhadap hipotesis keempat menunjukkan signifikasi hubungan antara kepuasan konsumen dan green repurchase intention. Pengujian menunjukkan hasil bahwa keofisien beta sebesar 0,470 bernilai positif. Nilai signifikansi 0,000 $<0,05$ mengindikasikan bahwa $\mathrm{H}_{0}$ ditolak dan $\mathrm{H}_{4}$ diterima. Hasil ini mempunyai arti bahwa kepuasan konsumen berpengaruh positif dan signifikan terhadap green repurchase intention. Hal ini menunjukkan bahwa kepuasan konsumen yang tinggi dari konsumen akan menyebabkan konsumen melakukan pembelian kembali atau green repurchase intention terhadap produk-produk dari Tupperware.

Hal ini menunjukkan hasil yang sejalan dengan penelitian terdahulu yang dilakukan oleh Fang et al. (2011) dimana menjelaskan bahwa niat membeli kembali yang paling dominan dipengaruhi oleh kepuasan konsumen. Dapat dinyatakan bahwa terdapat pengaruh positif dan signifikan dari kepuasan konsumen terhadap niat membeli kembali atau repurchase intention. Penelitian yang dilakukan oleh Huang et al. (2014) menunjukkan hasil kepuasan konsumen mempunyai efek positif dan signifikan pada niat membeli kembali. Selain itu penelitian yang dilakukan oleh Dharmayana \& Rahanatha (2017) mendapatkan hasil bahwa kepuasan konsumen berpengaruh positif dan signifikan terhadap niat membeli kembali atau green repurchase intention. Selanjutnya dalam penelitian ini akan menguji pengaruh antara kepercayaan atau green trust terhadap green repurchase intention. Hasil estimasi pada Tabel 15. menunjukkan bahwa pengujian terhadap hipotesis kelima menunjukkan signifikasi hubungan antara green trust dan green repurchase intention. Pengujian menunjukkan hasil bahwa 
keofisien beta positif sebesar 0,470 bernilai positif. Nilai signifikansi $0,007<0,05$ mengindikasikan bahwa $\mathrm{H}_{0}$ ditolak dan $\mathrm{H}_{5}$ diterima. Hasil ini mempunyai arti bahwa green trust berpengaruh positif dan signifikan terhadap green repurchase intention. Hal ini menunjukkan bahwa adanya kepercatyaan atau green trust yang tinggi terhadap produk-produk Tupperware akan menyebabkan konsumen melakukan pembelian kembali atau green repurchase intentiont erhadap produkproduk tersebut.

Hasil ini menunjukkan hal yang sama dengan penelitian terdahulu yang dilakukan oleh Farida \& Elia (2015) terhadap produk Starbuck menunjukkan bahwa green trust memiliki pengaruh positif signifikan terhadap green repurchase intention. Selain itu penelitian yang dilakukan oleh Lam et al. (2016) menunjukkan bahwa green trust memiliki pengaruh positif dan signifikan terhadap green repurchase intention. Penelitian lainnya dilakukan oleh Dewi \& Rastini (2016) juga menunjukkan bahwa green trust berpengaruh positif dan signifikan terhadap green repurchase intention. Berdasarkan perhitungan sobel sebelumnya, didapat nilai t hitung sebesar 9,628 $>1,96$. Artinya green trust secara positif signifikan memediasi pengaruh green perceived value terhadap green repurchase intention. Hal ini menunjukkan hipotesis keenam atau $\mathrm{H}_{6}$ diterima. Selain secara langsung, pengaruh green perceived value terhadap green repurchase intention akan semakin tinggi jika mampu meningkatkan green trust.

Hal ini sejalan dengan penelitian sebelumnya yang dilakukan oleh Chen \& Chang (2012) yang menyebutkan bahwa perusahaan perlu meningkatkan green trust pelanggan, karena terdapat efek mediasi positif signifikan green trust sehingga perusahaan dapat membangun green trust dari pelanggan untuk meningkatkan tingkat positif hubungan antara green perceived value dan green repurchase intention. Penelitian dari Dewi \& Rastini (2016) juga menunjukkan bahwa green trust secara signifikan memediasi pengaruh green perceived value terhadap green repurchase intention. Berdasarkan perhitungan sobel sebelumnya, didapat $\mathrm{t}$ hitung sebesar $10,886>1$,96. Artinya green trust secara positif signifikan memediasi pengaruh kepuasan konsumen terhadap green repurchase intention. Hal ini menunjukkan hipotesis ke tujuh atau $\mathrm{H}_{7}$ diterima. Selain secara langsung, pengaruh kepuasan konsumen terhadap green repurchase intention akan semakin tinggi jika mampu meningkatkan green trust.

Hasil dari penelitian ini sejalan dengan hasil yang ditunjukkan oleh penelitian terdahulu yang dilakukan oleh Putri \& Suparna (2014) dan Ha et al. (2010) yang menunjukkan bahwa trust atau kepercayaan dapat memediasi kepuasan konsumen terhadap niat membeli kembali atau green repurchase intention. Apabila konsumen merasa puas dengan produk-produk yang ditawarkan Tupperware, maka akan meningkatkan kepercayaan konsumen terhadap brand Tupperware itu sendiri. Tingginya kepuasan konsumen dan kepercayaan konsumen terhadap kinerja ramah lingkungan dari produk Tupperware, akan meningkatkan niat beli kembali konsumen terhadap produk - produk ramah lingkungan Tupperware atau green repurchase intention produk Tupperware.

Implikasi dari hasil penelitian mencakup dua hal, yaitu implikasi teoretis dan praktis. Implikasi teoretis berhubungan dengan kontribusi bagi perkembangan teori tentang peran green truast dalam memediasi pengaruh green perceived value 
dan kepuasan konsumen terhadap green repurchase intention. Sedangkan implikasi praktis berkaitan dengan kontribusi penelitian terhadap green repurchase intention konsumen produk Tupperware di Kota Denpasar. Berdasarkan hasil penelitian yang dilakukan menunjukkan bahwa penelitian ini telah mampu mengkonfirmasi beberapa penelitian terdahulu, sekaligus memperkuat penelitian terdahulu mengenai pengaruh green perceived value, kepuasan konsumen, dan green trust terhadap green repurchase intention.

Hasil penelitian ini diharapkan digunakan sebagai masukan bagi produsen Tupperware, sehingga dapat meningkatkan green repurchase intention atau niat beli koembali produk ramah lingkungan dengan memperhatikan green trust atau kepercayaan konsumen terhadap produk kinerja produk ramah lingkungan sebagai fokus utamanya. Sebab, dari hasil yang diperoleh, green trust selain secara langsung dapat mempengaruhi secara positif terhadap terciptanya green repurchase intention bisa dikatakan pula sebagai variabel yang dapat memediasi pengaruh antara green perceived value dan kepuasan konsumen terhadap green repurchase intention. Sesuai dengan hasil penelitian ini, indikator yang masih dapat ditingkatkan kembali oleh produsen adalah meningkatkan promosi mengenai program Tupperware green living sebagai kelebihan produk Tupperware yang ramah lingkungan.

Berdasarkan penelitian yang telah dilakukan, ditemukan beberapa keterbatasan dalam penelitian ini. Penelitian ini hanya sebatas meneliti mengenai pengaruh green perceived value, kepuasan konsumen dan green trust terhadap green reourchase intention di Kota Denpasar, serta hasil penelitian ini tidak dapat digeneralisir maupun tidak dapat digunakan pada daerah lain maupun pada produk lain. Selain itu, penelitian ini hanya sebatas pada konsumen produk Tupperware yang berada di Kota Denpasar, dalam lingkup yang relatif kecil, dengan pengambilan data secara cross section sehingga dapat menimbulkan hasil yang berbeda jika terdapat penelitian serupa di waktu dan tempat yang berbeda.

\section{SIMPULAN}

Berdasarkan hasil analisis penelitian dan hasil pembahasan pada bab sebelumnya maka simpulan dari penelitian ini adalah sebagai berikut Green perceived value berpengaruh positif signifikan terhadap green repurchase intention pada produk Tupperware di Kota Denpasar. Hal ini menunjukan bahwa jika green perceived value semakin meningkat maka akan meningkatkan pula green repurchase intention pada produk Tupperware di Kota Denpasar. Kepuasan konsumen berpengaruh positif signifikan terhadap green repurchase intention pada produk Tupperware di Kota Denpasar. Hal ini menunjukan bahwa jika kepuasan konsumen semakin meningkat maka akan meningkatkan pula green repurchase intention pada produk Tupperware di Kota Denpasar. Green perceived value berpengaruh positif signifikanterhadap green trust pada produk Tupperware di Kota Denpasar. Hal ini menunjukan bahwa jika green perceived value semakin meningkat maka akan meningkatkan pula green trust pada produk Tupperware di Kota Denpasar. Kepuasan konsumen berpengaruh terhadap green trust pada produk Tupperware di Kota Denpasar. Hal ini menunjukan bahwa jika kepuasan konsumen semakin meningkat maka akan meningkatkan pula green trust pada 
produk Tupperware di Kota Denpasar. Green trust berpengaruh terhadap green repurchase intention pada produk Tupperware di Kota Denpasar. Hal ini menunjukan bahwa jika green trust semakin meningkat maka akan meningkatkan pula green repurchase intention pada produk Tupperware di Kota Denpasar.

Green trust secara positif signifikan memediasi pengaruh green perceived value terhadap green repurchase intention pada produk Tupperware di Kota Denpasar. Hal ini menunjukan bahwa green perceived value memberikan dampak yang signifikan terhadap green repurchase intention jika di mediasi oleh green trust, yang berarti bahwa pengaruh green perceived value terhadap green repurchase intention akan diperkuat dengan adannya green trust. Green trust secara positif signifikan memediasi pengaruh kepuasan konsumen terhadap green repurchase intention pada produk Tupperware di Kota Denpasar. Hal ini menunjukan bahwa kepuasan konsumen memberikan dampak yang signifikan terhadap green repurchase intention jika di mediasi oleh green trust, yang berarti bahwa pengaruh kepuasan konsumen terhadap green repurchase intention akan diperkuat dengan adannya green trust.

Berdasarkan hasil penelitian maka beberapa saran yang diharapkan dapat membantu produsen dan distributor produk Tupperware di Kota Denpasar serta para peneliti selanjutnya yaitu : Berdasarkan hasil penelitian yang telah dilakukan menunjukkan bahwa green trust atau kepercayaan terhadap kinerja ramah lingkungan produk Tupperware mempunyai kontribusi paling besar terhadap green repurchase intention. Oleh karena itu produsen produk Tupperware di kota Denpasar perlu meyakinkan konsumen mengenai kelebihan-kelebihan Tupperware sebagai produk ramah lingkungan untuk meningkatkan green repurchase intention. Perusahaan diharapkan lebih mempromosikan program Tupperware Green Living agar konsumen mengetahui bawha produk Tupperware bukan semata-mata hanya produk rumah tangga berbahan plastik berkualitas tinggi tetapi juga turut menjaga lingkungan dengan mengurangi pemakaian kemasan sekali pakai. Bagi peneliti selanjutnya, diharapkan supaya mampu melakukan penelitian dengan cakupan yang lebih luas, dengan menambah variabel lain diluar penelitian ini. Selain itu, bagi peneliti selanjutnya diharapkan dapat melakukan penelitian dengan cakupan wilayah yang lebih luas.

\section{REFERENSI}

Andrila, B., \& Mousumi, R. (2015). Green products: an exploratory study on the consumer behaviour in emerging economies of the East. Journal of Cleaner Production, 8(7), 463-468.

Arseculeratne, \& Yazdanifard. (2014). How Green Marketing Can Create a Sustainable Competitive Advantage for a Business. International Business Research, 7(1), 130-137.

Cahyani, N. L. T. H., \& Wardana, I. M. (2017). Peran Green trust Dalam Memediasi Pengaruh Green Product Perception Terhadap Green repurchase intention. E-Journal Universitas Udayana, 6(6), 2933-2966. 
Chen, Y.-S., \& Chang, C.-H. (2012). Enhance Green Purchase Intentions: The Roles of Green perceived value, Green Perceived Risk, and Green trust. Management Decision, 50(3), 502-520.

Chen, Y. S., \& Chang, S. H. (2013). Greenwash and Green trust: The Mediation Effects of Green Consumer Confusion and Green Perceived Risk. J Bus Ethics, 1(14), 489-500.

Chiang, A., Chan, P., \& Nguyen, L. (2014). Do U.S. Food Companies Achieve Competitive Adventages by Implementing Green Strategies throughout their Supply Chains. Advances in Management and Applied Economic, 4(5), 4152.

Dewi, S. A., \& Rastini, N. M. (2016). Peran Green trust Memediasi Green perceived value Dan Green Perceived Risk Terhadap Green repurchase intention. E-Journal Universitas Udayana, 5(12), 8046-8078.

Dharmayana, I. M. A., \& Rahanatha, G. B. (2017). Pengaruh Brand Equity, Brand Trust, Brand Preference, dan Kepuasan Konsumen terhadap Niat Membeli Kembali. E-Journal Universitas Udayana, 6(4), 2018-2046.

Dwipayana, B., \& Sulistyawati, E. (2018). Peran Kepuasan dalam Memediasi Pengaruh Kepercayaan terhadap Niat Beli Ulang pada Go-Food di FEB Unud. E-Journal Universitas Udayana, 7(10), 5197-5229.

Falah, M., \& Ebrahimi, M. R. (2014). A Study on the Effect of Green Marketing on Consumers' Purchasing Intention. Management Science Letters, 4(1), $421-424$.

Fang, Y.-H., Chiu, C.-M., \& Wang, E. T. . (2011). Understanding Customers Satisfaction and Repurchase Intentions. Internet Research, 21(4), 479-503.

Farida, N., \& Elia, A. (2015). Repeat Purchase Intention Of Starbucks Consumers In Indonesia: A Green Brand Approach. UDK Journal, 27(2), 189-202.

Ha, H., Janda, S., \& Muthaly, S. . (2010). No A New Understanding of Satisfaction Model in E-re-purchase Situation. European Journal of Marketing, 44(7), 997-1016.

Huang, C.-C., Yen, S.-W., \& Liu, C.-Y. (2014). The Relationship Among Brand Equity, Customer Satisfaction, And Brand Resonance To Repurchase Intention of Cultural and Creative Industries In Taiwan. The International Journal of Organizational Innovation, 6(3), 106-121.

Kaveh, M., Mosavi, S. A., \& Ghaedi, M. (2012). The Application Of European Customer Satisfaction Index (ECSI) Model In Determining The Antecedents Of Satisfaction, Trust And Repurchase Intention In Five-Star 
Hotels In Shiraz, Iran. African Journal Of Business Management, 6(1), 6103-6113.

Lam, A. Y. C., Lau, M. M., \& Cheung, R. (2016). Modelling the Relationship among Green perceived value, Green trust, Satisfaction, and Repurch ase Intention of Green Products. Contemporary Management Research, 12(1), $47-60$.

Manchanda, R. (2014). Materialism And Green Purchase Behavior: Relationship Analysis. International Refereed Research Journal, 5(4), 10-20.

Masitoh, M. R., \& Widikusyanto, M. J. (2017). Pengaruh Kepuasan dan kepercayaan pelanggan pada Niat Beli Ulang Secara Online. Jurnal Sains Manajemen, 3(1), 50-68.

Norazah, M. S., \& Norbayah, M. S. (2016). Consumer Environmental Concern and Green Product Purchase in Malaysia: Structural Effects of Consumption Values. Journal of Cleaner Production, 13(2), 204-214.

Octaviany, R. P. (2016). Pengaruh Green perceived value Dan Green Perceived Risk Terhadap Green trust Dan Green Purchase Intention (Green Marketing) Studi Kasus pada Konsumen Lemari Es Merek LG di Kota Semarang. Jurnal Fakultas Ekonomi Dan Bisnis Universitas Dian Nuswantoro Semarang, 1(2), 20-30. https://doi.org/B11.2012.02600

Prastiwi, S. K. (2016). Menguji Faktor - Faktor yang Berpengaruh Terhadap Repurchase Intention Pada Produk Mie Instant Indomie Di Yogjakarta. Jurnal EKA CIDA, 1(1), 96 - 109.

Pratama, M. A. (2014). Profil Green Consumers Indonesia: Identifikasi Segmen Dan Faktor-Faktor Yang Mempengaruhi Perilaku Pembelian Green Poducts. Jurnal Ilmiah Mahasiswa Universitas Surabaya, 3(1), 13-24.

Putra, K. D. S. ., \& Rastini, N. M. (2017). Pengaruh Green perceived value Dan Green Perceived Quality Terhadap Green Satisfaction Dan Green trust. EJournal Universitas Udayana, 6(5), 2789-2816.

Putri, Y., \& Suparna, G. (2014). Peran Kebiasaan Membaca Label Dalam Memediasi Pengaruh Variabel Demografi Terhadap Niat Membeli Produk Hijau Merek Natur-E Di Kota Denpasar. E-Journal Universitas Udayana, 3(4), 975-987.

Risyamuka., I. ., \& Kastawan, M. (2015). Pengaruh Green Marketing Terhadap Keputusan Pembelian Produk Hijau di Restoran Sari Organik Ubud. EJurnal Manajemen Universitas Udayana, 4(2), 1-13. 
Romadon, Y., Srikandi, K., \& Yusri, A. (2014). Pengaruh Green Marketing Terhadap Brand Image Dan Struktur Keputusan Pembelian (Survei Pada Followers Account Twitter @Pertamaxind Pengguna Bahan Bakar Ramah Lingkungan Pertamax Series). Jurnal Administrasi Bisnis (JAB), 15(1), 313.

Rosannah, F. S. (2014). Pengaruh Kepercayaan dan Kepuasan Terhadap Merek Pada Niat Membeli Ulang. Siasat Bisnis, 18(1), 63-80.

Royer, S., Ferro, Â. n, Wilson, S., \& Karl, D. (2018). Production Of Methaneand Ethylenefrom Plastic In The Environment. PLoSONE, 13(8), 1-13. https://doi.org/10.1371

Sarawaty, W., \& Suprapti, N. W. S. (2015). Peran Sikap dalam Memediasi Pengaruh Kepedulian Lingkungan Terhadap Niat Beli Produk Ramah Lingkungan (Studi pada Produk Tupperware). E-Jurnal Manajemen Unud, 4(8), 2407-2427.

Sari, N. P. S. N., Yasa, N. N. K., \& Nurcaya, I. N. (2015). Peran Kepercayaan Dalam Memediasi Pengaruh Persepsi Risiko Terhadap Niat Beli (Studi Pada Konsumen Lampu Led Merek Philips Di Kota Denpasar). Jurnal Manajemen FEB Universitas Udayana. Juima, 5(1), 13-20.

Shaputra, R. K. (2013). Penerpan Green Marketing pada Bisnis Produk Kosmetik. Jurnal JIBEKA, 7(3), 47-53.

Suryana, P., \& Eliyandi, S. D. (2013). Analisis Faktor Yang Mempengaruhi Keputusan Pembelian dan Implikasinya Pada Minat Beli Ulang. Trikonomika, 12(2), 190-200. Retrieved from tupperware.co.id

Tariq, \& Zubair, M. (2014). Impact of Green Advertisement and Green Brand Awareness on Green Satisfaction with Mediating Effect of Buying Behavior. Journal of Managerial Sciences, 8(2), 274-289.

Waskito, J. (2015). Upaya Meningkatkan Niat Pembelian Produk Ramah Lingkungan Melalui Nilai, Risiko, Dan Kepercayaan Terhadap Produk Hijau. Etikonomi, 14(1), 1-10. 